\title{
A review of prominent theories in perceived CSR-employee outcomes link in hospitality literature
}

\author{
Erhan Boğan
}

Keywords:

Corporate social

responsibility,

Employee outcomes,

Hospitality literature

Article History:

Submitted: 17.12.2020

Accepted: 27.04.2021

\section{ABSTRACT}

\begin{abstract}
Researchers' interests to corporate social responsibility (CSR) concept is increasing in tourism and hospitality literature. Thus far, many papers published that examined what, how and when CSR practices provide economic returns including financial performance and various stakeholders' positive reactions. Although there are many papers related CSR-financial performance, as a critical stakeholder, employees' reactions to CSR practices are underinvestigated. Current study seeks to extend Boğan's (2020a) initial research by providing the key tenets of prominent theories that provide a theoretical foundation for researchers interested in investigating employees' reactions to CSR practices in hospitality industry. These theories include social identity theory, social exchange theory, stakeholder theory, self-determination theory, justice theory and signaling theory. We explicate the underlying psychological processes in CSR-employee outcomes link by drawing arguments from these critical six theories. The study will provide some important theoretical baseline for future researchers whose research interests include perceived CSR-employee outcomes link.
\end{abstract} Doi: https://doi.org/10.31822/jomat.2021-6-2-99

\section{Introduction}

In the tourism and hospitality literature, researchers' interest to concept of corporate social responsibility (CSR) is increasing (Boğan, 2020a; Boğan \& Sarışık, 2020; Gursoy et al., 2019). One of the possible reasons for this is the progress of the CSR in the management and marketing literature. Another important reason is the awareness that CSR is wider in scope than environmental practices associated with sustainable tourism (Coles, Fenclova \& Dinan, 2013). CSR imposes some responsibilities on businesses in order to accomplish sustainable development (Boğan, 2020b). In other words, CSR underlines that business have some economic, social, environmental and ethical responsibilities in the region where they operate (Carroll, 1979; Martínez, Pérez \& Rodriguez del Bosque, 2013).

It is possible to say that CSR practices have become a strategic trend regardless of the tourism and hospitality sector (Carroll \& Shabana, 2010). This is confirmed by CSR awards given by different organizations every year. However, when examined in the context of the tourism and hospitality industry, it is seen that many food companies, hotels and travel companies carry out social responsibility projects and share them on different channels in order to receive strategic returns from their stakeholders (de Grosbois, 2012; Holcomb, Upchurch \& Okumus, 2007; Okumus et al., 2020). For example, Hilton hotels communicate their social and environmental projects and objectives on corporate web pages (Hilton, 2021). Starbucks conveys its responsible initiatives and goals to its stakeholders under the titles of strengthen communities, green retail, create opportunities and source ethically and sustainably (starbucks.com/responsibility). Communicating such positive responsible initiatives to stakeholders results in getting positive returns (Boğan \& Dedeoğlu, 2019a).

In recent years, individual stakeholders' reactions to CSR practices in the hospitality industry have been investigated not only in developed countries but also in developing countries (Boğan \& Dedeoğlu, 2019a; Gursoy et al., 2019; Islam et al., 2016;). The responses of different stakeholder groups to CSR practices are called micro-CSR (Aguinis \& Glavas, 2012; Glavas, 2016). Researchers have used a number of theories to 
demonstrate what reactions stakeholders will have and why. Put another way, they put their research models on theoretical ground. Theory refers to "a consistent and coherent group of general propositions used as explanations for a class of phenomena" (Bormann, 1996, pp. 83). The present study aims to reveal the theories used to explain the reactions of employees to CSR practices. These theories will enable researchers to take advantage of the models they build in CSR in the future. The study will be based on the bibliometric results given in the study of Boğan (2020b). Accordingly, the author carried out a bibliometric study, which covers empirical studies published in Q1 code journals that investigate employees' reactions to CSR activities published in tourism and hospitality journals. In the context of the content, the author emphasized the theories that the researchers used, and revealed that the social identity theory and social exchange theory were the most used theory.

\section{Literature Review}

\section{Corporate Social Responsibility}

The modern concept of CSR dates to the 1950s (Frederick, 1960). The fact that companies underestimate social interest and exhibit environmentally irresponsible behaviours has attracted the reaction of communities, NGOs and consumers, especially the media. In previous periods when all ways were considered legitimate in order to maximize profit, companies displayed irresponsible examples. Child labor, not providing a healthy and safe working environment to employees, polluting the natural environment are just a few of these irresponsible behaviors. However, as a result of the pressure put on by the stakeholders, it has been generally accepted that companies have some social and environmental responsibilities beyond economic returns (Carroll, 1989). Therefore, the success of the company is measured not only by financial indicators, but also by responsible initiatives they exhibit in social and environmental terms (Serra-Cantallops et al., 2018).

According to Carroll (1979), the concept of CSR in the modern sense started with the book of "social responsibilities of businessmen" written by Bowen (1953). Bowen (1953, p. 6) stressed the "obligations of businessmen to pursue those policies, to make those decisions, or to follow those lines of action which are desirable in terms of the objectives and values of our society". Although there are many definitions for the concept of CSR, Dahlsrud (2008) has revealed that the definition that researchers use the most is that of the Commission of the
European Communities. Accordingly, EC (2001) defined CSR as "a concept whereby companies integrate social and environmental concerns in their business operations and in their interaction with their stakeholders on a voluntary basis". Carroll (1979) created a pyramid to demonstrate responsibilities of companies in four dimensions as economic, legal, ethical and philanthropic respectively. Economic responsibility is the primary responsibility that includes producing goods and services that society needs and selling them at a fair price. Legal responsibility requires compliance with legal regulations in the production and sale of goods and services. Ethical responsibilities, although not covered by legal regulations, it covers practices and activities that are not allowed or expected by the community. Finally, philanthropic responsibility is the responsibility area that people think in the first place when social responsibility is concerned. Philanthropic responsibility activies reflect the company's own desires and wishes, that is, not caused by external pressure (Carroll, 1979, 1989). These four dimensions have been largely used to measure employees' CSR perception in tourism and hospitality literature (Fu, Ye \& Law, 2014; Kim, Song \& Lee, 2016; Kim et al., 2017; Lee et al., 2012; Song et al., 2015).

\section{Perceived CSR and Employee Outcomes}

In tourism and hospitality literature, CSR practices initially linked to financial performance (Inoue \& Lee, 2011; Kang, Lee \& Huh, 2010; Qu, 2014; Rhou, Singal \& Koh, 2016; Youn, Hua \& Lee, 2015). But later, various stakeholders' (including customers, employees, local people and prospective employees) responses to CSR practices investigated. Among these stakeholders, there is only limited papers related to employees' responses (Aguinis \& Glavas, 2012; Glavas, 2016; SerraCantallops et al., 2018). Among these limited papers, researchers investigated the impact of employees' CSR perception on their work- and organization-related outcomes such as job satisfaction (Çalışkan \& Ünüsan, 2011; Lee et al., 2012; Youn, Lee \& Lee, 2018), organizational commitment (Fu, Ye \& Law, 2014; Islam et al., 2016; Kim, Song \& Lee, 2016; Song et al., 2015), work engagement (Ilkhanizadeh \& Karatepe, 2017; Park, Lee \& Kim, 2018), organizational trust (Boğan \& Dedeoğlu, 2019a; Lee et al., 2012, 2013), affective commitment (Boğan \& Sarışık, 2020; Kim et al., 2017; Wong \& Gao, 2014; Youn, Lee \& Lee, 2018), organizational identification (Fu, Ye \& Law, 2014; Islam et al., 2016; Park, Levy, 2014), innovative behavior (Park, Lee \& Kim, 2018), 
career satisfaction (Ilkhanizadeh \& Karatepe, 2017), organizational citizenship behavior (Fu, Ye \& Law, 2014; Islam et al., 2016; Kim et al., 2017), work-life quality (Kim et al., 2017), perceived organizational culture (Wong \& Gao, 2014) and voice behavior (Ilkhanizadeh \& Karatepe, 2017). The findings of most these papers indicated that hospitality companies CSR practices play an important role to enhance employees' positive work- and organizational-related attitudes and behaviors.

\section{Most Cited Theories in CSR-Employee Outcomes}

The researchers who examined the link between CSR and employee outcomes used some theories to provide theoretical background for the model they proposed. Among these theories, according to the findings of Boğan (2020), social identity theory (Ashforth \& Mael, 1989), social exchange theory (Blau, 1964), self-determination theory (Deci \& Ryan, 1985) and stakeholder theory (Freeman, 1984) are the most used theories in tourism and hospitality literature during the period of 20122019. We provide some critical explanations of these theories to future researchers. This may provide some important benefits to researchers while creating the research model. Beyond these four theories, we emphasize that justice theory (Cropanzano et al., 2001) and signaling theory (Rynes, 1991; Spence, 2002) are two of most used theories in management literature. Stakeholder theory (Freeman, 1984) is mostly used while measuring employees' CSR perception (Park et al., 2018; Park \& Levy, 2014; Wong \& Gao, 2014; Zientara et al., 2015). According to this theory, companies have some responsibility not only to internal stakeholders (owners, investors, employees) but also to external stakeholders (customers, suppliers, government, community groups etc.). Hence, they must take all stakeholders' interest into account in decision making process (Farmaki, 2019; Karakuş, Onat and Yetiş: 2018).

According to social identity theory (Ashforth \& Mael, 1989), people divide themselves and others into certain classes or categories. These classes or categories play an important role in the development or protection of the individual's selfconcept. These categories also help the individual to position themselves and others in the social environment. Depending on the high quality or attractiveness of the category, people have some perceptions that are reflected positively or negatively on their attitudes and behaviors towards to it. It is clear that companies, which generally show socially and environmentally responsible behavior, have a high corporate reputation among its stakeholders. Working in such a highly reputable company or being a part of this company contributes to the employee positioning himself in a good place in his social environment. In particular, when the positive activities of the company are discussed or mentioned in a social community, the employee will be proud of being a member of this organization. That may most likely shape his attitudes and behaviors to the organization (Fu et al., 2014; Islam et al., 2016; Kim et al., 2016a; Park \& Levy, 2014; Wong \& Gao, 2014; Youn et al., 2018).

According to social exchange theory (SET) (Blau, 1964; Deckop et al., 2003) there are two types of exchanges between the organization and employees as economic and social. The fact that the employee gives his labor and gains his wages from the company in return for the labor put into the work creates the economic dimension of this exchange. This exchange is clearly stated in the employment contract. Social exchange, on the other hand, is the non-monetary part of the employment and covers the voluntarily behaviors of the employee. For example, participating in a charity project organized by the company or participating in planting project. Employee participation in such responsible projects can lead to a spiritual satisfaction or meeting the need to make sense of his life. Ultimately, employees can provide positive feedbacks to the company that meets this need. That reflects the basic reciprocity tenet of social exchange theory (Boğan \& Dedeoğlu, 2020; Gürlek \& Tuna, 2019; Jones, 2010; Kim et al., 2017).

Another one of most cited theories is selfdetermination theory (Deci \& Ryan, 1985). Selfdetermination theory (SDT) focuses on the extent to which an individual's behavior is self-motivated and self-determined. According to this theory, the type of motivation (intrinsic versus extrinsic) that the individual has is the main determinant of the result of his behaviors. Socially responsible businesses engage in activities that provides benefits to both the business and the community. This is something beyond the economic and technical interest of the company (Aguilera et al., 2007). Employees' perception of CSR motivates them to enjoy their work, to satisfy their curiosity, and to meet their need of self-expression. Intrinsic motivation of employees working in a socially responsible enterprise is higher. Because, the 
company engages in practices accordance with the values of employees who are members of the wider community. Intrinsic motivated employees exhibit more positive work- and organization-related attitudes and behaviors. Since responsible initiatives increase intrinsic motivation, employees' CSR perception can be expected to reflect on their attitudes and behaviors (Hur, Moon \& Ko, 2018). Some CSR papers in hospitality literature (Hu, Liu \& Qu, 2019; Kim et al., 2016b) used SDT principles while developing the research model.

According to the justice theory (Cropanzano et al., 2001), employees want fair behaviors not only to themselves but also to their colleagues and even external stakeholders. This desire of employees arises from three types of individual needs. The employee wants to be treated fairly because this will reveal an individual benefit. He wants his colleagues to be treated fairly because he wants to belong to a group. He wants external stakeholders to be treated fairly because he wants to make sense of his life morally. This third need is a reflection of deontic justice. It is an important requirement of humanity not to remain silent against the injustices they witness even if it is not done to him. Because as much as he is concerned with himself, he is also concerned with his social environment. An individual living in Alaska is affected by hunger and famine in Africa or tsunami in Japan. Because the human nature requires that (Rupp et al., 2006). Here are some studies that used justice theory while developing the research hypotheses in tourism and hospitality literature (Boğan \& Dedeoğlu, 2019a, 2019b).

According to the signaling theory (Rynes, 1991; Spence, 2002), job seekers or individuals who have just started working in the company do not have enough information about the working conditions and business environment and how the company will treat them. In these issues, the company's outreach social and environmental initiatives provide some tips or signals to the job seekers in order to make predictions. Employees may think that the company will treat responsibly to them thanks to the responsible initiatives it displays in the external environment. Therefore, the company can be considered reliable or attractive due to these initiatives. As a result, individuals seeking a job can provide positive feedback, such as preferring the company as a good place to work or recommending it to others looking for a job (Boğan \& Dedeoğlu, 2019b).

\section{Conclusion}

The interest of researchers in CSR practices, which we frequently encounter in the tourism and hospitality sector, is increasing day by day (Boğan \& Dedeoğlu, 2019a, 2020). So much so, over the past few years, researchers have developed complex models covering the reactions of different stakeholders to these practices (see Boğan \& Dedeoğlu, 2020; Boğan \& Sarışık, 2020; Gursoy et al., 2019; Kim et al., 2017; Su et al., 2017; Su \& Swanson, 2019;). In other words, the researchers are trying to reveal what, how and when the CSR practices result in positive stakeholder reactions. The findings obtained guide the practitioners in the form of a compass. The current study examines the theories used to explain the reactions of employees to CSR practices in the tourism and hospitality industry. Employees' attitudes and behaviors are critical to the success of companies operating in the service industry. Namely, employees are critical in shaping customers' service quality perception, customer satisfaction and loyalty (Boğan \& Dedeoğlu, 2017; Heskett \& Schlesinger, 1994). Among these theories, some of the most commonly used principles of social identity theory, social exchange theory, stakeholder theory, justice theory, selfdetermination theory and signaling are explained. This provides a comprehensive guide especially for the researchers who are interested in CSR and environmental practices. In this way, researchers will be able to express more easily what kind of contributions the research models they have created theoretically. Considering that the studies carried out especially in the tourism and hospitality sector have some theoretical shortcomings (Faulkner \& Goeldner, 1998; Rivera \& Pizam, 2015), the current study can be expected to guide researchers.

\section{References}

Aguilera, R. V., Rupp, D. E., Williams, C. A., \& Ganapathi, J. (2007). Putting the $\mathrm{S}$ back in corporate social responsibility: A multilevel theory of social change in organizations. Academy of Management Review, 32(3), 836-863.

Aguinis, H., \& Glavas, A. (2012). What we know and don't know about corporate social responsibility: A review and research agenda. Journal of Management, 38(4), 932-968.

Ashforth, B. E., \& Mael, F. (1989). Social identity theory and the organization. Academy of Management Review, 14(1), 20-39.

Blau, P. M. (1964). Exchange and power in social life. New York: John Wiley 
Boğan, E. (2020a). Turizm evağırlama sektöründe çalışanların kurumsal sosyal sorumluluk faaliyetlerine yönelik tepkileri üzerine bibliyometrik bir çalışma. Seyahat ve Otel İsletmeciliği Dergisi, 17(1), 87-102.

Boğan, E. (2020b). Sorumlu turizm. In A. Olcay (Ed.), Alternatif turizm (pp. 143-164), Gazi Kitapevi: Ankara.

Boğan, E., \& Dedeoğlu, B. B. (2017). The effects of perceived behavioral integrity of supervisors on employee outcomes: Moderating effects of tenure. Journal of Hospitality Marketing \& Management, 26(5), 511-531.

Boğan, E., \& Dedeoğlu, B. B. (2019a). The effects of hotel employees' CSR perceptions on trust in organization: Moderating role of employees' selfexperienced CSR perceptions. Journal of Hospitality and Tourism Insights, 2(4), 391-408.

Boğan, E., \& Dedeoğlu, B. B. (2019b). The influence of corporate social responsibility in hospitality establishments on students' level of commitment and intention to recommend. Journal of Hospitality, Leisure, Sport \& Tourism Education, $25,100205$.

Boğan, E., \& Dedeoğlu, B. B. (2020). How hotel employees' perception of CSR increase organizational citizenship behavior: Mediating mechanisms of perceived external prestige and pride in organization, Corporate Social Responsibility and Environmental Management, 27(5), 2342-2353.

Boğan, E., \& Sarışık, M. (2020). Organization-related determinants of employees' CSR motive attributions and affective commitment in hospitality companies. Journal of Hospitality and Tourism Management, 45, 58-66.

Bormann, E. G. (1996). Symbolic convergence theory and communication in group decision making. In R. Y. Hirokawa \& M. S. Poole (Eds.), Communication and group decision making (2nd ed., pp. 81-113). Thousand Oaks, CA: Sage.

Bowen, H. P. (1953). Social responsibilities of the businessman. Harper, New York.

Carroll, A. B. (1979). A three-dimensional conceptual model of corporate performance. Academy of Management Review, 4(4), 497-505.

Carroll, A. B. (1989). Business and society: Ethics and stakeholder management. 2nd Edition, SouthWestern Publishing Co. USA, Ohio.

Carroll, A. B., \& Shabana, K. M. (2010). The business case for corporate social responsibility: A review of concepts, research and practice. International Journal of Management Reviews, 12(1), 85-105.

Coles, T., Fenclova, E., \& Dinan, C. (2013). Tourism and corporate social responsibility: A critical review and research agenda. Tourism Management Perspectives, 6, 122-141.

Cropanzano, R., Byrne, Z. S., Bobocel, D. R., \& Rupp, D. E. (2001). Moral virtues, fairness heuristics, social entities, and other denizens of organizational justice. Journal of Vocational Behavior, 58(2), 164-209.

Çalışkan, O., \& Ünüsan. Ç. (2011). Hotel employee perceptions of corporate social responsibility and its effects on job satisfaction and intention to stay, Anatolia: Turizm Arastirmalari Dergisi, 22(2), 154-166.

Dahlsrud, A. (2008). How corporate social responsibility is defined: an analysis of 37 definitions. Corporate Social Responsibility and Environmental Management, 15(1), 1-13.

De Grosbois, D. (2012). Corporate social responsibility reporting by the global hotel industry: Commitment, initiatives and performance. International Journal of Hospitality Management, 31(3), 896-905.

Deci, E. L., \& Ryan, R. M. (1985). Intrinsic motivation and self-determination in human behavior. New York: Plenum.

Deckop, J. R., Cirka, C. C., \& Andersson, L. M. (2003). Doing unto others: The reciprocity of helping behavior in organizations. Journal of Business Ethics, 47(2), 101-113.

EC (European Commission). (2001). Promoting a European framework for corporate social responsibility. Green Paper, 264 Final, Brussels, Belgium

Farmaki, A. (2019). Corporate social responsibility in hotels: a stakeholder approach. International Journal of Contemporary Hospitality Management, 31, 2297-2320.

Faulkner, B., \& Goeldner, C. R. (1998). Progress in tourism and hospitality research. Journal of Travel Research, 37(1), 76-80.

Frederick, W. C. (1960). The growing concern over business responsibility. California Management Review, 2(4), 54-61.

Freeman, E. (1984). Strategic Management: A Stakeholder Approach. Pitman Publishing, Boston.

Fu, H., Ye, B. H., \& Law, R. (2014). You do well and I do well? The behavioral consequences of corporate social responsibility. International Journal of Hospitality Management, 40, 62-70.

Glavas, A. (2016). Corporate social responsibility and organizational psychology: An integrative review. Frontiers in Psychology, 7(144), 1-13.

Gursoy, D., Boğan, E., Dedeoğlu, B. B., \& Çalışkan, C. (2019). Residents' perceptions of hotels' corporate 
social responsibility initiatives and its impact on residents' sentiments to community and support for additional tourism development. Journal of Hospitality and Tourism Management, 39, 117128.

Gürlek, M., \& Tuna, M. (2019). Corporate social responsibility and work engagement: Evidence from the hotel industry. Tourism Management Perspectives, 31, 195-208.

Heskett, J. L., \& Schlesinger, L. A. (1994). Putting the service-profit chain to work. Harvard Business Review, 72(2), 164-174.

Hilton. (2021). Travel with purpose. Retrieved from https://cr.hilton.com/

Holcomb, J. L., Upchurch, R. S., \& Okumus, F. (2007) Corporate social responsibility: what are top hotel companies reporting?. International Journal of Contemporary Hospitality Management, 19(6), 461-475.

Hu, B., Liu, J., \& Qu, H. (2019). The employee-focused outcomes of CSR participation: The mediating role of psychological needs satisfaction. Journal of Hospitality and Tourism Management, 41, 129137.

Hur, W. M., Moon, T. W., \& Ko, S. H. (2018). How employees' perceptions of CSR increase employee creativity: Mediating mechanisms of compassion at work and intrinsic motivation. Journal of Business Ethics, 153(3), 629-644.

Ilkhanizadeh, S., \& Karatepe, O. M. (2017). An examination of the consequences of corporate social responsibility in the airline industry: Work engagement, career satisfaction, and voice behavior. Journal of Air Transport Management, 59, 8-17.

Inoue, Y., \& Lee, S. (2011). Effects of different dimensions of corporate social responsibility on corporate financial performance in tourismrelated industries. Tourism Management, 32(4), 790-804.

Islam, T., Ahmed, I., Ali, G., \& Sadiq, T. (2016). Behavioral and psychological consequences of corporate social responsibility: need of the time. Social Responsibility Journal, 12(2), 307-320.

Jones, D. A. (2010). Does serving the community also serve the company? Using organizational identification and social exchange theories to understand employee responses to a volunteerism programme. Journal of Occupational and Organizational Psychology, 83(4), 857-878.

Kang, K. H., Lee, S., \& Huh, C. (2010). Impacts of positive and negative corporate social responsibility activities on company performance in the hospitality industry. International Journal of Hospitality Management, 29(1), 72-82.
Karakuş, Y., Onat, G., \& Yetiş, Ş. A. (2018). Yöneticilerin, Aşçların Yetkinliklerine Yönelik Beklentilerinin Değerlendirilmesi. Journal of Tourism and Gastronomy Studies, 6(4), 299-321.

Kim, H. L., Rhou, Y., Uysal, M., \& Kwon, N. (2017). An examination of the links between corporate social responsibility (CSR) and its internal consequences. International Journal of Hospitality Management, 61, 26-34.

Kim, J. S., Song, H. J., \& Lee, C. K. (2016a). Effects of corporate social responsibility and internal marketing on organizational commitment and turnover intentions. International Journal of Hospitality Management, 55, 25-32.

Kim, S. H., Kim, M., Han, H. S., \& Holland, S. (2016b). The determinants of hospitality employees' proenvironmental behaviors: The moderating role of generational differences. International Journal of Hospitality Management, 52, 56-67.

Lee, C. K., Song, H. J., Lee, H. M., Lee, S., \& Bernhard, B. J. (2013). The impact of CSR on casino employees' organizational trust, job satisfaction, and customer orientation: An empirical examination of responsible gambling strategies. International Journal of Hospitality Management, 33, 406-415.

Lee, Y. K., Lee, K. H., \& Li, D. X. (2012). The impact of CSR on relationship quality and relationship outcomes: A perspective of service employees. International Journal of Hospitality Management, 31(3), 745-756.

Martínez, P., Pérez, A., \& Rodriguez del Bosque, I. (2013). Measuring corporate social responsibility in tourism: Development and validation of an efficient measurement scale in the hospitality industry. Journal of Travel \& Tourism Marketing; 30(4), 365-385.

Okumus, F., Sengur, F. K., Koseoglu, M. A., \& Sengur, Y. (2020). What do companies report for their corporate social responsibility practices on their corporate websites? Evidence from a global airline company. Journal of Hospitality and Tourism Technology, 11(3), 385-405.

Park, S. Y., \& Levy, S. E. (2014). Corporate social responsibility: perspectives of hotel frontline employees. International Journal of Contemporary Hospitality Management, 26(3), 332-348.

Park, S. Y., Lee, C. K., \& Kim, H. (2018). The influence of corporate social responsibility on travel company employees. International Journal of Contemporary Hospitality Management, 30(1), 178-196.

$\mathrm{Qu}$, R. (2014). Market orientation and organizational performance linkage in Chinese hotels: The mediating roles of corporate social responsibility 
and customer satisfaction. Asia Pacific Journal of Tourism Research, 19(12), 1399-1416.

Rhou, Y., Singal, M., \& Koh, Y. (2016). CSR and financial performance: The role of CSR awareness in the restaurant industry. International Journal of Hospitality Management, 57, 30-39.

Rivera, M. A., \& Pizam, A. (2015). Advances in hospitality research: "from Rodney Dangerfield to Aretha Franklin". International Journal of Contemporary Hospitality Management, 27(3), 362-378.

Rupp, D. E., Ganapathi, J., Aguilera, R. V., \& Williams, C. A. (2006). Employee reactions to corporate social responsibility: An organizational justice framework. Journal of Organizational Behavior: The International Journal of Industrial, Occupational and Organizational Psychology and Behavior, 27(4), 537-543.

Rynes, S. L. (1991). Recruitment, job choice, and posthire consequences, in Dunnette, M.D. (Ed.), Handbook of Industrial and Organizational Psychology (pp. 399-444), 2nd ed., Consulting Psychologists Press, Palo Alto, CA.

Serra-Cantallops, A., Peña-Miranda, D. D., RamónCardona, J., \& Martorell-Cunill, O. (2018). Progress in research on CSR and the hotel industry (2006-2015). Cornell Hospitality Quarterly, 59(1), 15-38.

Song, H. J., Lee, H. M., Lee, C. K., \& Song, S. J. (2015). The role of CSR and responsible gambling in casino employees' organizational commitment, job satisfaction, and customer orientation. Asia Pacific Journal of Tourism Research, 20(4), 455471.

Spence, M. (2002). Signaling in retrospect and the informational structure of markets. American Economic Review, 92(3), 434-459

Su, L., \& Swanson, S. R. (2019). Perceived corporate social responsibility's impact on the well-being and supportive green behaviors of hotel employees: The mediating role of the employeecorporate relationship. Tourism Management, 72, 437-450.

Su, L., Swanson, S. R., Hsu, M., \& Chen, X. (2017). How does perceived corporate social responsibility contribute to green consumer behavior of Chinese tourists. International Journal of Contemporary Hospitality Management, 29(12), 3157-3176.

Wong, I. A., \& Gao, J. H. (2014). Exploring the direct and indirect effects of CSR on organizational commitment. International Journal of Contemporary Hospitality Management, 26(4), 500-525.

Youn, H., Hua, N., \& Lee, S. (2015). Does size matter? Corporate social responsibility and firm performance in the restaurant industry. International Journal of Hospitality Management, 51, 127-134.

Youn, H., Lee, K., \& Lee, S. (2018). Effects of corporate social responsibility on employees in the casino industry. Tourism Management, 68, 328-335.

Zientara, P., Kujawski, L., \& Bohdanowicz-Godfrey, P. (2015). Corporate social responsibility and employee attitudes: evidence from a study of Polish hotel employees. Journal of Sustainable Tourism, 23(6), 859-880. 


\title{
INFO PAGE
}

\section{A review of prominent theories in perceived CSR-employee outcomes link in hospitality literature}

\begin{abstract}
Researchers' interests to corporate social responsibility (CSR) concept is increasing in tourism and hospitality literature. Thus far, many papers published that examined what, how and when CSR practices provide economic returns including financial performance and various stakeholders' positive reactions. Although there are many papers related CSR-financial performance, as a critical stakeholder, employees' reactions to CSR practices are underinvestigated. Current study seeks to extend Boğan's (2020a) initial research by providing the key tenets of prominent theories that provide a theoretical foundation for researchers interested in investigating employees' reactions to CSR practices in hospitality industry. These theories include social identity theory, social exchange theory, stakeholder theory, self-determination theory, justice theory and signaling theory. We explicate the underlying psychological processes in CSR-employee outcomes link by drawing arguments from these critical six theories. The study will provide some important theoretical baseline for future researchers whose research interests include perceived CSR-employee outcomes link.
\end{abstract}

Keywords: Corporate social responsibility, Employee outcomes, Hospitality literature

\section{Authors}

Author statement: Author(s) declare(s) that All procedures performed in studies involving human participants were in accordance with the ethical standards of the institutional and/or national research committee and with the 1964 Helsinki declaration and its later amendments or comparable ethical standards.

This paper does not required ethics committee report Justification: The methodology of this study does not require an ethics committee report. 